\title{
Insured Pension Funds - Who Benefits?
}

Peggy J. Crawford, (peggy.crawford@pepperdine.edu), Pepperdine University

Edward H. Fredericks, Jr., (edward.fredericks@pepperdine.edu), Pepperdine University

\author{
ABSTRACT \\ The defined pension plans of many firms are underfunded. The Pension Benefits Guaranty \\ Corporation was created to protect retirees, but who really benefits?
}

\section{INTRODUCTION}

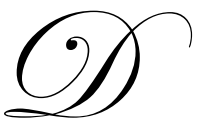

efined benefit pension plans have popped up in the news as more and more employees and retirees find that their "guaranteed" retirement plans are not so "guaranteed!" Workers were reminded of the vulnerability of these plans when United Airlines (UA), after declaring bankruptcy, terminated its pension funds in 2005 and turned over its pension liabilities to the Pension Benefits Guaranty Corporation (PBGC). The $\$ 7.1$ billion liability was the largest ever received by PBGC.

PBGC was created to protect the beneficiaries of defined benefit plans. However after the UA termination, questions about the financial condition and viability of defined benefit pension funds have been raised by many including members of Congress. That is, why did UA feel it was necessary to terminate its plan before it could leave bankruptcy? Data suggest that the pension plan was substantially underfunded and the firm's future viability depended on the offloading of this liability. So, who benefits from PBGC - the beneficiaries or the firms?

In this paper, we will examine the defined benefit plans of Fortune 500 companies. The current market value of the assets of these plans, the current liability of these plans, the return assumptions used by management for funding purposes, the performance of the funds' investments, and managements' reactions to shortfalls will be analyzed.

\section{PENSION INSURANCE}

The Pension Benefits Guaranty Corporation was established by the Employee Retirement Income Security Act of 1974. The purpose of this Act was to provide security to workers and retirees covered by defined benefit plans. Defined benefit plans promise an annuity to the beneficiaries - the amount usually based on salary and/or number of years of service - over their lives. If an insured plan is terminated, the PBGC takes over the plan and its pension liabilities. It then pays retirees up to the limit set by the law. Typically this means a reduction (sometimes large) in the expected income of retirees. For example, the four largest terminations in PBGCs history created pension liabilities of $\$ 18$ billion. PBGC paid $2 / 3$ of the claims handing a $\$ 6$ billion loss to plan participants. UAs 122,541 vested participants, on the other hand, had on average an annual claim of $\$ 87,889$ while the maximum annual payment by PBGC when the plan was terminated was $\$ 45,614$ - almost a 50 percent reduction in benefits!

There are two types of plans covered by PBGC. The largest are the "single employer" plans which protect 34 million workers and retirees in 28,800 different plans. The others are the "multi-employer" plans which are normally created in union negotiations and protect a group of workers such as those in a particular industry. Currently 9.9 million workers and retirees in 1,540 plans fall in this category. As of September 30, 2005, underfunding in plans classified as "reasonably possible terminations" or firms with a high degree of default risk (normally measured as those with bonds rated below investment grade) amounted to $\$ 108$ billion. Total underfunding in single employer defined benefit PGBC insured plans exceeded $\$ 450$ billion. 
PBGC is not funded by tax-payer dollars, but rather receives its funds through premium payments from firms that sponsor insured pension plans. PBGC invests the premiums (the PBGC fund) and supports its activities with income from the fund and balances from terminated plans. Terminated plans can impact firms which retain insurance by depleting the PGCB fund and causing premiums to be increased. The Deficit Reduction Act of 2005 reflects this reality, and raised premiums for both single-employee and multi-employee plans. This increased the cost of "doing business" for well run firms.

\section{PENSION PLAN FUNDING}

To examine the financial viability of defined benefit funds, we can look at the condition of Fortune 500 firms. As shown in Table 1, 238 firms were overfunded in 2000 versus 110 underfunded firms. The market turndown and recession beginning in 2001 reversed this relationship and by 2004, 55 were overfunded versus 319 underfunded plans. Estimates suggest that this relationship will continue to deteriorate. Funding status (the ratio of plan assets to obligations) decreased from 123 percent to an expected 87 percent in 2006.

Table 1

Changing Fund Status of Fortune 500 Companies

$\begin{array}{rrrrrrrr} & \underline{2000} & \underline{2001} & \underline{2002} & \underline{2003} & \underline{2004} & \underline{2005 e} & \underline{2006 e} \\ \text { Number of Companies Overfunded } & 238 & 122 & 35 & 50 & 55 & 42 & 45 \\ \text { Number of Companies Underfunded } & 110 & 237 & 335 & 320 & 319 & 325 & 322 \\ \text { Plan Assets } & \$ 1,168 & \$ 1,040 & \$ 950 & \$ 1,138 & \$ 1,268 & \$ 1,243 & \$ 1,264 \\ \text { Pension Benefit Obligation (PBO) } & \$ 948 & \$ 1,031 & \$ 1,168 & \$ 1,314 & \$ 1,433 & \$ 1,461 & \$ 1,448 \\ \text { Funded Status \$ } & \$ 220 & \$ 9 & -\$ 218 & -\$ 176 & -\$ 165 & -\$ 218 & -\$ 183 \\ \text { Funded Status \% } & 123 \% & 101 \% & 81 \% & 87 \% & 89 \% & 85 \% & 87 \%\end{array}$

\section{CAUSES OF UNDERFUNDING}

What has caused this change? Part of the answer is found in how defined pension plans are structured. Each year the firm and/or participants contribute money to a fund which invests the dollars in money and/or capital market securities. The amount contributed is based on three factors. First is the life expectancy of the participant after retirement. That is, how many years will the participant draw the promised annuity. Second is the size of the expected annuity. That is, how large is the promised annuity - again size is typically based on salary and/or years of service. Third is the expected return that the invested funds will earn over the working life of the participant. That is, as annual contributions are received, what return will the invested funds earn prior to withdrawal by the retiree.

Firms make assumptions as to these three values. While data is available to help estimate the first two, the third assumption is critical and uncertain. Table 2 shows the median assumption of investment return and the actual return earned by invested funds. In five out of the seven years reported (including expected values), the actual return on invested pension funds was below the assumptions on which contributions were calculated. In two of these years assumed returns exceeded actual returns by 16 percent!

It is important to remember that defined benefit pension plan funds should be invested in fairly sound securities. Participants are expecting to receive the promised annuities at retirement. So, the contributions should not be invested in overly risky securities. Table 2 shows that in years when the return on short-term Treasury securities hovered around 1 percent, firms were basing their pension contributions on an assumed return above 8 percent. 
Table 2

Pension Fund Performance of Fortune 500 Companies

$\begin{array}{rrrrrrrrr} & \underline{2000} & \underline{2001} & \underline{2002} & \underline{2003} & & \underline{2004} & \underline{2005 e} & \underline{2006 e} \\ \text { No. Firms w/ Pretax Pension Income } & 144 & 144 & 91 & 45 & & 32 & 32 \\ \text { No. Firms w/Pretax Pension Expense } & 195 & 204 & 267 & 320 & 344 & 339 & 339 \\ \text { After-Tax Pension_\% of Net Income* } & -2.00 \% & -2.00 \% & 1.00 \% & 4.00 \% & 4.00 \% & 3.00 \% & 2.00 \% \\ \text { Median Expected Return } & 9.31 \% & 9.25 \% & 8.80 \% & 8.50 \% & 8.35 \% & 8.35 \% & 8.35 \% \\ \text { Median Actual Return } & 4.34 \% & -5.96 \% & -8.86 \% & 18.06 \% & 11.48 \% & 2.00 \% & 7.17 \% \\ \text { Median Liability Discount Rate } & 7.50 \% & 7.25 \% & 6.25 \% & 6.10 \% & 5.75 \% & 5.75 \% & 6.00 \% \\ \text { Median Salary Inflation Rate } & 4.50 \% & 4.50 \% & 4.15 \% & 4.00 \% & 4.00 \% & 4.00 \% & 4.00 \%\end{array}$

Note: Income is shown as a negative and Expense as a postive number.

The period 2000 - 2005 was a volatile time for the markets. Table 3 compares the median expected and actual returns on Fortune 500 companies' pension funds (from Table 2 above) to the actual performance of a series of Vanguard Index Funds. ${ }^{2}$ The selected funds include both bond and stock funds. The return on the Fortune 500 Index illustrates the lackluster performance of these firms as returns in three of the six years were negative. It also reflects the volatility they faced. Returns increased by approximately 50 percent between 2002 and 2003, increasing from a return of -22.15 percent to 28.50 percent. The last column of the table gives the arithmetic average of returns over the six year period. It is interesting to note that only three funds averaged the expected returns of the pension funds during this period - both long-term bond funds and Mid-Cap Growth. It is also interesting to note that the actual return on pension funds was the third lowest return earned. Only the Large Blend Cap and Fortune 500 index earned lower returns during the period.

\begin{tabular}{|c|c|c|c|c|c|c|c|}
\hline \multicolumn{8}{|c|}{$\begin{array}{c}\text { Table } 3 \\
\text { Market Performance }\end{array}$} \\
\hline & $\underline{2000}$ & 2001 & 2002 & 2003 & $\underline{2004}$ & 2005 & Average \\
\hline Pension Fund Median Expected Return & $9.31 \%$ & $9.25 \%$ & $8.80 \%$ & $8.50 \%$ & $8.35 \%$ & $8.35 \%$ & $8.76 \%$ \\
\hline Pension Fund Median Actual Return & $4.34 \%$ & $-5.96 \%$ & $-8.86 \%$ & $18.06 \%$ & $11.48 \%$ & $2.00 \%$ & $3.51 \%$ \\
\hline 500 Index & $-9.06 \%$ & $-12.02 \%$ & $-22.15 \%$ & $28.50 \%$ & $10.74 \%$ & $4.77 \%$ & $0.13 \%$ \\
\hline Long-term Government Bonds & $19.72 \%$ & $4.31 \%$ & $16.67 \%$ & $2.68 \%$ & $7.12 \%$ & $6.61 \%$ & $9.52 \%$ \\
\hline Long-term Bonds & $16.63 \%$ & $8.17 \%$ & $14.35 \%$ & $5.50 \%$ & $8.40 \%$ & $5.32 \%$ & $9.73 \%$ \\
\hline Large Blend Cap & $-8.97 \%$ & $-11.13 \%$ & $-21.92 \%$ & $30.15 \%$ & $11.11 \%$ & $5.82 \%$ & $0.84 \%$ \\
\hline Mid-cap Blend & $-15.51 \%$ & $-9.17 \%$ & $-18.06 \%$ & $43.43 \%$ & $18.71 \%$ & $10.29 \%$ & $4.95 \%$ \\
\hline Large Value & $13.57 \%$ & $-2.34 \%$ & $-15.65 \%$ & $25.14 \%$ & $13.57 \%$ & $4.37 \%$ & $6.44 \%$ \\
\hline Mid-cap Growth & $18.04 \%$ & $-9.68 \%$ & $-27.94 \%$ & $49.55 \%$ & $21.65 \%$ & $8.27 \%$ & $9.98 \%$ \\
\hline
\end{tabular}

With the short-fall in funding expected to continue, firms should be taking actions to manage their pension funds. Short-falls can be eliminated in one of two ways - by either decreasing the expected payouts to the retirees or by increasing the amount of money employees contribute to their retirement fund. Which of these actions is management taking? 


\section{DECREASED EXPECTATIONS?}

If defined benefit pension plans are underfunded, management can reduce this problem by decreasing expected payouts in the future. This can be accomplished by changing the plan from a defined benefit to a defined contribution plan or by reducing the number of retirees through buyouts.

The most notable firm to change the form of its pension plan was IBM. In January 2006, IBM announced that it would end its defined benefits plan as of January 2008. ${ }^{3}$ They stated that the current defined benefit plan would be replaced with a redesigned $401 \mathrm{~K}$ plan. A $401 \mathrm{~K}$ plan is a defined contribution plan. With this type of plan, the contribution is fixed, but the amount available at retirement depends on the returns earned by the invested contributions. IBM announced it would increase its contribution to a maximum of 10 percent of the employees' salary and provide for 100 percent participation. The stated rationale for the change was to better control retirement costs by creating a more predictable cost structure. A defined contribution plan allows a firm to better control its pension costs because the uncertainty of market returns is borne by the retiree, not the firm.

A notable example of the second is General Motors (GM). In March 2006, GM announced a plan to buyout its workers. ${ }^{4}$ Employees' possible payout depended on years of service. If the individual had worked for GM for less than 10 years, he/she could receive up to $\$ 70,000$ if they would retire and severe all ties - no retirement benefits. If the individual had worked for GM between 10 and 26 years, the possible payout increased to a maximum of $\$ 140,000$ if retirement benefits were surrendered. This plan would allow GM to substantially reduce its costs. Because of union contracts, the average worker costs GM $\$ 130,000$ per year. If the employee takes early retirement, the cost drops to $\$ 50,000$ per year. After the employee qualifies for Social Security and Medicare, the cost drops to $\$ 20,000$ per year. A large number of employees $-35,000$ - took the buyout. Many analysts believe this cost savings will increase the viability of GM and help it return to profitability.

\section{INCREASED FUNDING?}

If defined benefit pension plans are underfunded, management can reduce this problem by increasing their contribution to the fund. This can be accomplished by diverting cash from other actions such as cash dividends and stock repurchases - both of which should benefit shareholders. So, the question is have Fortune 500 firms held dividends steady(decreases in dividends typically lead to large drops in stock price and would not be expected) to provide cash for pension fund contributions? Or have firms reduced the amount of cash they have spent on repurchasing outstanding common stock?

In 2003, 14 percent of firms increased their dividend payout and in 2004, 7 percent increased their dividend payout. ${ }^{5}$ The increased dividend payouts were a reaction to changes in the personal income tax laws which went into effect in 2003. At that time, the top federal tax rate on most dividends paid to individuals was reduced from 38.6 percent to 15 percent - the lowest rate since World War I. Firms reacted by increasing their payouts to shareholders even as the number of underfunded plans became dangerously high. It appears that management decided to reward shareholders at the expense of workers and retirees. The question is did insurance provided by PGBS allow or encourage them to take this action?

Repurchase of outstanding shares benefit shareholders by providing them with cash (if they sell) or increasing the value of their shares (if they don't). Repurchases may also benefit management by reducing the number of shares outstanding if a shareholder is attempting to gain control of the company. Companies on the Standard \& Poor's 500 stock index announced \$164 billion in stock repurchases in the first two quarters of 2005. Many analysts believe the repurchases are being driven by a one-year tax break which allows U.S. companies to repatriate huge sums from overseas. While the law does not allow for repatriated cash to be used for repurchases, companies are not required to isolate the profits brought back or pledge them to certain activities. Again it appears that management decided to reward shareholders - and themselves - at the expense of pension plans. 


\section{CONCLUSION}

So, what does this mean? PBCGs future exposure to probable terminations declined in 2006 from 2005 estimates. The health of pension funds was helped by several years of double-digit investment gains and rising interest rates. However, the shortfall still stands at $\$ 73$ billion and many plans are still at risk for termination. In addition, it is estimated that on average 64 percent of pension assets are invested in the stock market - suggesting another market downturn could again wreak havoc with pension funding. ${ }^{6}$ If the plans are terminated, retirees can expect a sometimes significant decrease in retirement income.

And, what is management doing to reduce this shortfall? Some firms are reducing their future retirement liabilities. They are either switching from defined benefits to defined contribution plans or encouraging employees to walk away from retirement benefits through buyouts. Evidence suggests that firms are not diverting additional cash into funds to decrease the shortfall. Instead, it appears that firms have increased dividend and repurchase payouts to shareholders while continuing to increase the risk to workers and retirees.

What this means to retirees then is more risk and uncertainty about the future. If plans are terminated, retirees face greatly reduced retirement income. If defined benefit plans are replaced with defined contribution plans, workers face more uncertainty as to retirement income. Retirement income will depend on market returns.

The future looks less favorable for retirees. Or, there goes that retirement home on the $18^{\text {th }}$ hole.

\section{END NOTES}

1. Data for Tables 1 and 2 appeared in David Zion and Bill Carcashe, Pension Plans Getting Weaker This Year, CSFB Pension Update, 25 October 2005.

2. Data on Vanguard Mutual Funds' performance obtained from Yahoo Finance. Data is actual performance - interest or dividends plus price change - for each of the funds listed. Funds listed by investment philosophy.

3. IBM Press Release, IBM Changes U.S. Pension Plan, Effective in 2008, as Part of Ongoing Global Retirement Strategy Shift, 5 January 2006.

4. CNNMoney.com, GM offers workers up to $\$ 140,000$ to leave, 22 March 2006.

5. Petruno, Tom, More Companies Increase Dividends, The Los Angeles Times, 4 January 2005, p. C-1.

6. Francis, Theo, Pension Plans Take Healthy Turn, The Wall Street Journal, 23 January 2007, p. A-4. 


\section{NOTES}

